Reviews in Aquaculture

March 2017, Volume 9, Issue 1, Pages 23-41

http://dx.doi.org/10.1111/raq.12100

Achimer

http://archimer.ifremer.fr/doc/00270/38097/

(C) 2015 Wiley Publishing Asia Pty Ltd

\title{
Coping styles in farmed fish: consequences for aquaculture
}

\author{
Castanheira Maria Filipa ${ }^{1,{ }^{*}}$, Conceição Luís E.C. ${ }^{1,2}$, Millot Sandie ${ }^{3}$, Rey Stephanie ${ }^{4,5}$, \\ Bégout Marie-Laure $^{3}$, Damsgård Børge ${ }^{6}$, Kristiansen Tove ${ }^{7}$, Höglund Erik ${ }^{8,9}$, Øverli Øyvind ${ }^{10}$, \\ Martins Catarina I.M. ${ }^{1}$
}

${ }^{1}$ CCMAR-CIMAR L.A.; Centro de Ciências do Mar; Universidade do Algarve; Faro Portugal

${ }^{2}$ Sparos Lda; Área Empresarial de Marim; Olhão Portugal

${ }^{3}$ Laboratoire Ressources Halieutiques; Ifremer; L'Houmeau France

4 Institut de Biotecnologia i Biomedicina; Universitat Autonoma de Barcelona; Barcelona Spain

${ }^{5}$ Institute of Aquaculture; University of Stirling; Stirling Stirlingshire UK

${ }^{6}$ Faculty of Biosciences, Fisheries and Economy; University of Tromsø; Tromsø Norway

${ }^{7}$ Institute of Marine Research; Bergen Norway

${ }^{8}$ Section for Aquaculture; The North Sea Research Centre; DTU Aqua; Technical University of Denmark; Hirtshals Denmark

${ }_{9}^{9}$ Department of Research Management; University of Agder; Kristiansand Norway

${ }^{10}$ Department of Animal and Aquacultural Sciences; Norwegian University of Life Sciences; Ås Norway

*Corresponding author : Maria Filipa Castanheira, email address : maria.filipa.castanheira@gmail.com

\begin{abstract}
:
Individual differences in physiological and behavioural responses to stressors are increasingly recognised as adaptive variation and thus raw material for evolution and fish farming improvements including selective breeding. Such individual variation has been evolutionarily conserved and is present in all vertebrate taxa including fish. In farmed animals, the interest in consistent trait associations, that is coping styles, has increased dramatically over the last years because many studies have demonstrated links to performance traits, health and disease susceptibility and welfare. This study will review (i) the main behavioural, neuroendocrine, cognitive and emotional differences between reactive and proactive coping styles in farmed fish; (ii) the methodological approaches used to identify coping styles in farmed fish, including individual (group) mass-screening tests; and (iii) how knowledge on coping styles may contribute to improved sustainability of the aquaculture industry, including welfare and performance of farmed fish. Moreover, we will suggest areas for future research, where genetic basis (heritability/epigenetic) of coping styles, and the neuroendocrine mechanisms behind consistent as well as flexible behavioural patterns are pinpointed as central themes. In addition, the ontogeny of coping styles and the influence of age, social context and environmental change in coping styles will also be discussed.
\end{abstract}

Keywords : behavioural syndromes, farm animals, individual variation, personality, stress response 


\section{Introduction}

In animals, including fish, individual differences in response to challenges are associated with differences in behaviour (Øverli et al. 2007; Réale et al. 2010). Many of these associations have been shown to be consistent under stressful conditions and thus to represent coping styles in accordance with the definition by Koolhaas et al. (1999), as a coherent set of behavioural and physiological stress responses, which is consistent over time and which is characteristic to a certain group of individuals'. Terminology remains one of the main challenges when addressing the topic of consistent individual variation in physiology and behaviour. Other authors use terms such as behavioural syndromes (Sih et al. 2004), personality (Gosling 2001) and temperament (Francis 1990) more or less synonymously, while physiologists tend to refer to coping styles. These terms and designated definitions, share common grounds such as the recognition that individual variation may be consistent and biologically meaningful, and individual differences in certain behavioural traits are consistent and predictive of other behaviours or physiological responses shown in another context. Typically, in biomedical research and agricultural sciences the term —oping styles" is preferred, while in behavioural ecology the terms behavioural syndromes are more common. The range of biological parameters considered also differs between the different terms. Coping styles often include both behavioural and physiological responses to unfavourable environments and stress (Koolhaas et al. 1999) while behavioural syndromes include only behavioural differences and not necessarily under stress conditions. Personality and temperament, in humans, include essentially emotional reactivity traits. However, when applied to animals, the term personality often ignores the emotional component. Table 1 summarises the terminology concerning individual variation. Recognising that both physiological and behavioural traits are important, throughout this review the term -Copingstyles" will be used in accordance with the definition by Koolhaas et al. (1999, see above).

In fish, the importance of understanding mechanisms involved in coping styles have gained increasing attention. Especially since, conditions that are well tolerated by some individuals may be detrimental to others, the concept of coping styles are important for their welfare 
92 (Huntingford \& Adams 2005; Huntingford et al. 2006), health and diseases resistance (Fevolden

93

94 et al. 1992,1993; MacKenzie et al. 2009, Kittilsen et al. 2012), performance traits (Martins 2005, Martins et al. 2011b; Øverli et al. 2006 ab) and interpretations of molecular data (Johansen et al. 2012; MacKenzie et al. 2009; Rey et al. 2013).

Moreover, Martins et al (2011b) showed that coping styles are predictive of how stimuli are appraised, supporting the inclusion of emotional or affective states (in this case fear) as essential component of coping styles in fish. Also Millot et al (2014a) shown that fish are able to retain memories of events with positive/negative valence which are retrieved by environmental cues.

Table 2 summarises the main behavioural and physiological differences between reactive and proactive individuals. Nevertheless, it is imperative to note that the differentiation in coping styles may not be expressed as a binomial distribution in most of the species but rather as a continuous distribution with the majority of individuals expressing intermediate characteristics. In addition, Boersma (2011) suggested that the relative occurrence of contrasting coping styles depends on the type of population (i.e. wild or domesticated). This author showed that in wild populations of rats, the coping strategies of the individuals within a population display a binomial distribution: with extremes proactive vs. reactive individuals. Rats with an intermediate coping style are generally not present in a population in the wild since they have a lower fitness in both stable and new or instable environments. In contrast, Réale et al. (2007, $2010 \mathrm{ab}$ ) demonstrated a normal distribution of coping styles in the wild in several species. Moreover, in laboratory or domestic settings there is less environmental pressure pushing the population into a bimodal distribution of coping styles. This means that in domesticated population a normal distribution in coping styles is usually observed (Spoolder et al. 1996).

Nowadays, stress coping styles are clearly identified in fish and have contributed to the understanding of individual variation in the ability to cope with stressful events. A consensus is emerging that increased understanding of the consequences of stress coping styles in aquaculture is important to safeguard a sustainable development of this industry. 
119 This study will review: 1) the main behavioural, neuroendocrine, cognitive and emotional 120 differences between reactive and proactive coping styles in farmed fish, 2) the methodological 121 approaches used to identify coping styles in farmed fish; including individual (group) massscreening tests and 3) how knowledge on coping styles may contribute to improved sustainability of the aquaculture industry, including welfare and performance of farmed fish.

\section{Assessment of coping styles in farmed animals}

Land farm animals

Assessment of coping styles in farm animals gained momentum in the late 1980's. In those studies researchers applied the concept of coping styles to domestic livestock and started to understand how distinct individual traits were related with stress coping under common rearing conditions. For instance, in piglets, the most common test is the - bck test" (Hessing et al. 1993,1994) which consists of restraining each piglet in a supine position for 1 min and classification of pigs is then based on the number of escape attempts made. Other tests commonly used in pigs and other farm animals like cows, cattle and sheep are the open field test (Spoolder et al. 1996; Magnani et al. 2012 ; Van Reenen et al. 2005), the novel object test (Spoolder et al. 1996; Magnani et al. 2012; Spake et al. 2012; Van Reenen et al. 2005), the novel environment test (Hopster, 1998) and the resident intruder test (Bolhuis et al. 2005a; Spake et al. 2012). Along with behavioural responses also physiological responses are measured including cortisol responsiveness, heart rate (Korte et al. 1999), gastric ulceration and vocalisation (Hessing et al. 1993; Ruis et al. 2001; Van Reenen et al. 2002; van Erp-van der Kooij et al. 2003; Van Reenen et al. 2005; Hopster, 1998; Spake et al. 2012).

Several traits attributed to proactive and reactive individuals in land farmed animals have also been identified in fish suggesting that many of such traits have been evolutionary conserved in vertebrates (see references below). 
Identifying coping styles in farmed fish

Over the last years, the number of papers addressing coping styles in fish has raised rapidly. Many of these studies address farmed fish including common carp (Cyprinus carpio) (MacKenzie et al. 2009; Huntingford et al. 2010), Nile tilapia (Barreto \& Volpato 2011; Martins et al. 2011bd), Atlantic salmon (Salmo salar) (Kittilsen et al. 2009a, 2012; Vaz-Serrano et al. 2011), Atlantic halibut (Hippoglossus hippoglossus) (Kristiansen \& Fernö 2007), rainbow trout (Øverli et al. 2005, 2006ab; Schjolden et al. 2005; Ruiz-Gomez et al. 2008, 2011; Höglund et et al. 2008; Laursen et al. 2011) ), sea bass (Millot et al. 2009 ab) and gilthead seabream (Castanheira et al. 2013ab; Herrera et al. 2014) Table 2.

Like in mammals, two main coping styles are typically recognised: proactive (active coping or bold or fight-flight') and reactive (passive coping or shy or non-aggressive').

Typically, proactive individuals are behaviourally characterized by: 1) active escape from a stressor (Brelin et al. 2005; Laursen et al. 201; Silva et al. 2010; Martins et al. 2011c); 2) high feed efficiency (Martins et al. 2005ab, 2006ab; van de Nieuwegiessen et al. 2008); 3) high feeding motivation after transfer to a new environment (Øverli et al. 2007) or food type (Kristiansen \& Fernö 2007); 4) high risk taking and exploratory when exposed to novelty (Huntingford et al. 2010; Øverli et al. 2006a; MacKenzie et al. 2009; Millot et al. 2009a); 5) high social rank (dominant) during aggressive encounters (Øverli et al. 2004, 2005; Castanheira et al. 2013a); 6) low social influence (Magnhagen, 2007; Magnhagen \& Staffan 2005; Magnhagen \& Bunnefeld, 2009); 7) low sensitive to environmental stressors (Höglund et al. 2008); 8) establishment of routines and have less behavioural flexibility (Chapman et al. 2010; Ruiz-Gomez et al. 2011) when compared to reactive individuals. Proactive individuals exhibit typical physiological and neuroendocrine characteristics such as: 1) lower hypothalamuspituitary-interrenal (HPI) activity (Silva et al. 2010), as measured by basal cortisol levels; 2) lower HPI reactivity (Castanheira et al. 2013a; Øverli et al. 2007; Trenzado et al. 2003), as measured by increase in cortisol over basal levels when stressed; 3) higher sympathetic reactivity and lower parasympathetic reactivity (Verbeek et al. 2008; Barreto \& Volpato 2011), measured as opercular beat rate; 4) low hormonal modulation (LeBlanc et al. 2012); 5) higher 
oxygen consumption during stress (Herrera et al. 2014; Killen et al. 2011; Martins et al. 2011c); 6) lower myocardial dysfunction (Johansen et al. 2011); 7) lower neural plasticity (Johansen et al. 2012) and 8) high immunity (Kittilsen et al. 2012) when compared to reactive individuals. In addition to behaviour, physiological and neuroendocrine characteristics, proactive and reactive fish have also been reported to differ in cognitive and emotional traits. One of the best examples of the characterization of coping styles in fish comes from studies using selected lines of rainbow trout (Oncorhynchus mykiss). These lines were segregated into high- and lowresponding individuals (HR, LR) on the basis of their plasma cortisol response after confinement test (Pottinger \& Carrick 1999). Studies in these lines demonstrated a link between cognition and coping styles: Moreira et al. (2004) showed that HR-LR individuals differed in memory retention in addition to cortisol responsiveness. The extinction of a conditioned response (i.e. how quickly the conditioned response was lost after the end of reinforcement) was greater among LR individuals.

In accordance with this, Ruiz-Gomez et al. (2011) showed a higher propensity to develop and follow routines (reversal learning) in LR trout. They continue to perform a learned pattern even if the conditions change. LR fish showed slower reversal learning when finding relocated feed, and it was suggested that this reflects a cognitive difference, where LR fish have a stronger tendency to develop and follow routines. This is in accordance with what have been suggested as general differences between proactive and reactive individuals, where reactive individuals react to environmental changes while proactive individuals follow predictions of the actual environment (Coppens et al. 2010).

Various methodologies used to characterise coping styles in fish have been adapted from those used in land farmed animals, an example is the restraining test, which is very similar to the back-test commonly used in pigs. The restraining test in fish consists of holding each individual in an emerged net for a certain limited period depending on the species (Arends et al. 1999; Silva et al. 2010; Castanheira et al. $2013 \mathrm{ab}$ ). While in the net, the following behaviours have been measured: latency to escape, number of escape attempts and total time spent on escape attempts. Proactive individuals have been shown to exhibit more and longer escape attempts as 
compared to reactive individuals (Silva et al. 2010; Martins et al. 2011ac). Other tests used in land farmed animals that have been adapted and applied to fish include the novel object test (Frost et al. 2007; Basic et al. 2012), the exploration test (Chapman et al. 2010; Killen et al. 2011; Magnhagen \& Staffan 2005; Magnhagen \& Bunnefeld 2009 and the resident intruder test (Øverli et al. 2002ab; Brelin et al. 2005).

Recent studies using farmed fish as models have suggested the possibility to discriminate coping styles using grouped-based test (e.g. hypoxia test developed in rainbow trout by Laursen et al. (2011) and adapted to gilthead seabream by Castanheira et al. 2013b). Briefly, the hypoxia test consists of reducing the oxygen levels in one side of a two chambers tank and measuring the escape behaviour from the hypoxia to the normoxia side. Another group-based test is the risktaking test (or exploration test) which consists of a tank separated in two distinct areas: safe and risk areas. Fish are placed in the safe area (darkened settling chamber), connected by a plastic tunnel or an opening to a risk area (open field). The risk area is usually associated to feed delivery zone to stimulate fish going to the non-familiar area (Millot et al. 2009; Huntingford et al. 2010; Castanheira et al. 2013b).

Finally, it should be noted that an increasing number of studies also report that contrasting coping styles in fish are reflected in somatic and morphological traits such as developmental rate (Andersson et al. 2011, 2013ab) and pigmentation patterns (Kittilsen et al., 2009ab, 2012; Bäckström et al. 2014). Genetic markers for variable stress resistance are also increasingly explored (Rexroad et al., 2012). Thus, tools to characterise coping styles and personality traits in fish are becoming increasingly available which fulfils an important prerequisite for the effort towards understanding both the biological background and applied potential of this type of individual variation.

The presence of coping styles in the most important farmed fish species and the common tests used are presented in Table 3. 


\section{Consistency and plasticity of coping styles in farmed fish}

One of the major gaps in the literature concerning the characterization of coping styles in animals, including fish, is the lack of knowledge on the consistency of individual differences. This includes knowledge on both contextual consistency i.e. the extent to which scores for behaviour expressed in one context are correlated across individuals with scores for behaviour expressed in one or more other contexts, when behaviour in all of the contexts is measured at the same age and time" and temporal consistency i.e. the extent to which scores for behaviour in a given context at a given time are correlated across individuals with scores for the same behaviour in the same context at a later time“ (Stamps \& Groothuis 2010).

Studies in the HR/LR rainbow trout lines showed that proactive and reactive individuals exhibit consistent traits. Over a period of 7 days, feeding responses after transfer into a novel environment, responses to a novel object, aggressiveness and responses to confinement were behaviourally constant, but no differences between lines were apparent (Basic et al. 2012). The ontogenic consistency of these traits where also demonstrate by Höglund et al. (2008) and Andersson et al. (2011, 2013ab).

However, most of the studies on coping styles characterization have been done on selected HR LR fish lines (Øverli et al. 2005, 2007) which raises the question whether similar consistency responses can be observed in non-selected populations. In line with the previous information, recent studies on non-selected populations seem to support the consistency of behavioural responses both over time and across-context. Castanheira et al. (2013b) using a non-selected population of gilthead seabream (Sparus aurata) showed that individual differences in risktaking behaviour and escaping behaviour in response to stressors are consistent over a period of 15 days. Moreover the same authors also showed that some behaviour can be used to predict other behaviours expressed in a different context (e.g. individuals that took longer to recover feed intake after transfer into a novel environment, exhibited higher escape attempts during a restraining test and escaped faster from hypoxia conditions).

Consistency of individual differences is a key element to identify coping styles in fish. However, this does not exclude the possibility that individuals change their coping style over 
time and context. In fact individual plasticity i.e. the extent to which the behaviour expressed by individuals with a given genotype in a given context at a given age and time varies as a function of the set of conditions experienced by those individuals before the behaviour was expressed` (Stamps \& Groothuis 2010), is very important because it allows individuals to adjust their behaviour to novel or instable environments. Few studies have addressed how plastic, proactive and reactive coping styles are. Frost et al. (2007) suggested that social context is an important modulator of coping styles in rainbow trout. These authors showed that bold individuals observing another's losing fights or with lower responses to novelty (novel objects and novel prey) reduced their boldness. However, shy individuals just alter their behaviour (increase their boldness responsiveness) when their relative competitive ability was similar or higher than their conspecifics. These results suggest that bold individuals may be more flexible to changing conditions as opposed to shy individuals (Frost et al. 2007). Similar differences in behavioural plasticity have been documented during feeding response in presence of the novel object. Basic et al. (2012) showed that proactive individuals adopt a more flexible behaviour by suppressing feed intake in presence of the novel object. In contrast, Ruiz-Gomez et al. (2011) have reported opposite results, i.e. LR (proactive) individuals seem to be more fixed in responses (relocated feed) when confronted with a new situation in contrast with HR individuals.

276 Individuals differ in how the environmental stimuli are appraised and how they are able to 277 adjust and adapt their physiology and behaviour to help them cope more effectively. Part of this 278 plasticity is supported and influenced by cognition and neural plasticity. The underlying neurobiological mechanism underpinning differences in plasticity between reactive and proactive individuals have been recently studied by Johansen et al. (2012) in the HR/LR rainbow trout lines. These authors measured genes involved in neural plasticity and neurogenesis (PCNA, BDNF, NeuroD and DCX) using quantitative PCR in brains of rainbow trout under baseline conditions and in response to short-term confinement and long-term social stress. They showed that a higher degree of neural plasticity in reactive individuals might 
285 provide the ideal conditions to support their higher behavioural flexibility as opposed to 286 proactive individuals.

287 Furthermore, Ebbesson \& Braithwaite (2012) reviewed the influence of neural plasticity and cognition shaped by the environmental experiences in several fish species. These authors agree that, neural plasticity aids in the adaptation and flexibility, demanding by the diverse environments in which fishes live. These, make the brain more sensitive to the surrounding environment moulding the adaptive responses to the environment both over the individual life and over evolutionary time.

However, there is still a long way to go in understanding plasticity of coping styles in order to improve the management and welfare of aquaculture populations.

Aspects of how coping styles change with age, social context and new environmental conditions should be explored in the future. Environmental changes might be particularly relevant during this era of an ongoing global climate change. Global warming could cause changes in species behaviour and life history (Kling et al. 2003). The impacts of climate change in aquaculture can be direct e.g. changes in water temperature, or indirect such as the increase of fishmeal costs and its consequences for aquaculture feeds. The recent approach by Dingemanse et al. (2009) offers a theoretical framework to help understanding plasticity of coping styles. They proposed the concept of behavioural reaction norms, i.e. measuring individual behavioural response over an environmental gradient (e.g. social environment, environmental changes). According to the same authors the same behaviour can be measured over multiple environmental gradients and individual behaviour can be described as a linear regression line linking the response with the environmental conditions. In the linear regression the intercept of the line describes the average individual level of the behaviour and the slope represents the individual degree of plasticity. Using temperature as an environmental gradient, on a recent work with zebrafish, Rey et al. 2014 (submitted) showed differences in thermal preferences for proactive and reactive fish under a thermal gradient. Proactive individuals preferred higher temperatures than reactive reflecting differences already detected on basal metabolic rates and different acclimation and environmental adaptation capacities between both coping styles. 


\section{Proxies for measuring coping styles in fish}

Coping styles characterization in fish can be time consuming, especially when individual-based tests are used. Therefore, several proxies have been suggested in the literature to characterize coping styles without the need to undertake complex behavioural tests.

Ventilation rate has been shown to be a sensitive indicator of fish physiological responses to stress. Barreto \& Volpato (2011) observed that ventilation rates of Nile tilapia were correlated with the feeding resumption in isolation. Individuals with high ventilation rates resumed feeding later than fish with low ventilation rates.

Skin pigmentation has also been suggested to predict coping styles in fish (Kittilsen et al. 2009 ab; 2012). High spotted Salmonids showed lower cortisol levels than lower spotted conspecifics (Figure 1). Visual markers provide a suitable tool that can be easily combined with other common procedures, such as size-grading or vaccination. Furthermore, Kittilsen et al. (2012) provided evidence for individual variation in parasites incidences while screening distinct coping styles. Individuals with high incidence of black skin spots harboured fewer ectoparasites (sea lice) as compared to less pigmented fish.

Observations of ear and tail postures are reliable non-invasive method for assessing emotional reactivity in pigs (Reimert et al. 2013) and sheep (Reefmann et al. 2009) and have been suggested as proxies for coping styles screening. In fish very little is known about the link between body postures and coping styles. Recently, Martins et al. (2012) used fin spreads (defined as a sudden elevation of the dorsal fin) to distinguish bold and shy individuals of the colonial fish, Neolamprologus caudopunctatus. Results showed that reactive individuals exhibited a higher number of fin spreads in response to novelty.

The time to reach the first feeding in Salmonids has also been suggested to predict coping styles. Recently, Andersson et al. (2013b) reported a coupling between stress coping styles and the time to reach first feeding (low cortisol responders had larger yolk reserves at emergence time) which can be used as a proxy.

What are the consequences of different stress coping styles in farmed fish for Aquaculture? 
341 The presence of coping styles is now well recognised in farmed fish and its implication for

342 aquaculture can be widespread. Individual fish within a population often differ in how strongly

343 they respond, behaviourally and physiologically, under stress conditions. A failure to

344 accommodate the coping styles of fish under farming conditions can lead to problems linked

345 with production (e.g. aggression, growth and disease resistance).

Growth performance and energetics

348 One of the best examples of the implications of coping styles in performance traits comes from studies with African catfish (Martins 2005). By studying individual differences in growth and how these relate with individual differences in feed intake, feeding behaviour and feed efficiency, Martins (2005) showed that the most efficient individuals were those reacting quicker to the presence of pellets and consuming their meals faster after transfer into a novel environment. These individuals were also those that exhibited a lower cortisol response after acute stress. All these characteristics (better feed efficiency and lower stress responsiveness) are clearly beneficial under aquaculture conditions.

Several studies revealed that coping styles play an important role in growth performance and feed conversion. In common carp the competitive ability (success in gaining access to a spatially restricted feed source) was shown to be consistent over time and related to risk-taking behaviour (Huntingford et al. 2010). The same behavioural characteristics have been observed on sea bass (Millot et al. 2009b). Data from Martins et al. (2011 abd) have shown that proactive individuals (Nile tilapia) seem to exhibit a faster recovery of feed intake after transfer and to use feed resources more efficiently. In Atlantic salmon conditions that normally prevail in intensive rearing systems (e.g. restricted feeding regimes, high density) may favour proactive individuals (Huntingford 2004; Huntingford \& Adams 2005).

Coping styles have also been linked with differences in metabolism (Huntingford et al. 2010; Martins et al. 2011c). In nature, the metabolic rate of an animal is linked to the willingness of risk-taking while foraging (Careau et al. 2008). Hence, increased energetic requirements in individuals with a higher metabolic demand could require them to forage more often or take 
more risks to achieve a higher rate of feed intake (Abrahams \& Sutterlin 1999; Finstad et al. 2007). Huntingford et al. (2010) and Herrera et al. (2014) reported that in carp and seabream respectively the risk-taking behavioural phenotype is associated with a relatively high metabolic rate, while the risk-avoiding phenotype is associated with a lower rate. Killen et al. (2011) reported in sea bass that the amount of risk-taking among individuals was positively correlated with their routine metabolic rate. However, Martins et al. (2011c) have reported opposite results in metabolic rate (oxygen consumption) measured when Senegalese sole were housed in respirometry chambers. These authors suggested that different individuals reacted differently when housed in the metabolic chambers that functioned as confinement chambers. Individuals that consumed less oxygen in a respirometry chamber were also the individuals that reacted sooner to a confinement stress (typical from proactive coppers). This apparent contradiction may have to do with the passive benthic life-style sole, compared to other more active fish species.

In addition, yolk-sac fry originating from the HR strain were more sensitive to environmental stressors, and have shown a shorter reaction time to low oxygen levels (Höglund et al. 2008). This suggests that differences in coping styles are expressed at early developmental stages before social or environmental interference. Proactive individuals seem to have a $\rightarrow$ fst" development strategy (or fast pace of life) as demonstrated by an earlier hatching and consumption of egg yolk reserves as compared to reactive (Andersson \& Höglund, 2012). Such life strategy has an impact on metabolic needs and most likely on the nutritional requirements. For instance, optimal dietary lipid content could depend on coping styles because metabolic rates are different and hence energy requirements could vary.

In rats metabolic differences between coping styles have been associated with metabolic diseases (Boersma 2011). Using selected Roman Low Avoidance (RLA) and Roman High avoidance (RHA) rats Boersma (2011) showed that different strains differ in plasma insulin levels, both in baseline conditions and during the intravenous glucose tolerance tests. Reactive RLA individuals were associated with insulin resistance and elevated levels of plasma leptin, 
free fatty acids levels, liver triglycerides, and an increased visceral fat content, especially when over feeding a high fat diet. Proactive RHA individuals were extremely resistant to diet-induced insulin resistance. Thus, coping styles of an individual seems to be associated with particular metabolic and (patho-) physiological characteristics.

\section{Selection programmes}

Selection programmes in farmed fish focus essentially on growth performance (Gjedrem 2005). As shown by Martins et al. (2005c) individuals exhibiting fast growth are often included in a proactive coping style. However, proactive individuals have also been shown to be more aggressive (Øverli et al. 2004; Castanheira et al. 2013a). Selection for fast growing individuals may results in co-selection of undesirable traits such as aggression. Aggressiveness has been linked with a diversity of aquaculture problems including decreased feed intake, growth dispersion, chronic stress and disease vulnerability (Ashley 2007). Furthermore, fighting brings a significant cost in terms of increased energy expenditure that may promote inefficient growth. In addition, aggression among fish in production systems can be a cause of skin and fin damage. This damage can directly reduce the value of the farmed product and increase the vulnerability to diseases. Moreover, proactive individuals have also been shown to develop routines more easily (Ruiz-Gomez et al. 2008, 2011; Basic et al. 2012; Frost et al. 2007). Such characteristic may be more advantageous under stable conditions provided by intensive husbandry systems but prejudicial in extensive or semi-intensive husbandry systems with lower standardized conditions.

\section{Disease resistance and parasites}

Another important implication of coping styles in farmed fish is the different disease susceptibility exhibited by proactive and reactive individuals. Diseases are one of the main challenges in aquaculture and can represent a considerable financial burden to the farmer. Studies on inflammatory challenge with bacterial pathogens reported distinct disease resistance between coping styles (Fevolden et al. 1992, 1993; MacKenzie et al. 2009). 
424 Fevolden et al. (1993) suggested selection targeting distinct coping styles rather than for

425 specific immune traits, selecting for a broad spectrum of defence mechanisms and hence

426 affecting resistance to several diseases.

427 Moreover, MacKenzie et al. (2009) showed distinct regulation of proinflammatory gene expression suggesting that fundamental differences in cytokine regulation exist in fish with distinct coping styles. In particular, tumor necrosis factor-alpha (TNF $\alpha)$ and interleukin 1-beta (IL1 $\beta$ ), putative cytokines involved in the development of inflammation in fish, differed between proactive and reactive individuals.

Among the diseases, Salmon lice are considered a major threat to marine Salmonids farming (Johnson et al. 2004) the evidence that salmon with higher black skin spots harboured fewer mature female lice carrying egg sacs suggests that individual host traits may decrease parasite infestation. Moreover (Øverli et al. 2014) demonstrate that the presence of sea lice affect behaviour and brain serotonergic activity in Atlantic salmon. Still, further studies should address the biology behind coping styles and resistance to parasites, bacteria and viruses. Furthermore, (Kittilsen et al. 2009b) established that distinct pigmentation profiles are correlated with stress cortisol response in Salmonids (Figure 1). Low cortisol responders were found to be consistently more spotted than high cortisol responders. Another study by the same authors Kittilsen et al. (2012) provided evidence for individual variation in parasites resistance to sea lice particularly, salmon louse (Lapeophtheiras salmonis) carrying egg sacs.

\section{Fish welfare}

In most fish species, chronic or acute stress is considered as the main factor reducing animal welfare in intensive husbandry productions (Ashley 2007; Huntingford et al. 2006). However, despite the link between acute response to challenges and coping styles very little information is available about chronic stressors and coping styles.

449 One of the best examples used to discriminate distinct susceptibility to chronic stressors was

450 performed using selected lines of wild house-mice. Strains of mice have been created through selective breeding for divergent hypothalamic-pituitary-adrenal axis responses to a standardized 
aggressiveness test: Short Attack Latency, high aggressive/ proactive (SAL) and Long Attack Latency, low to non-aggressive/ reactive (LAL) (Benus et al. 1991). Using these lines, Veenema et al. (2003) showed that response to a chronic stressor resulted in symptoms in LAL (proactive) mice characterized by decreased body weight, elevated plasma adrenocorticotropic hormone (ACTH) and corticosterone levels and a lower hippocampal mineralocorticoid receptor (MR): glucocorticoid receptor (GR) ratio.

Korte et al. (2005) mention that adaptive processes, actively maintain stability through change (allostasis) are dependent on the personality type and associated stress responses. The benefits of allostasis and the costs of adaptation (allostatic load) lead to different trade-off in health and stress related diseases, reinforcing that both coping styles (proactive/reactive) can be successful, under different environmental conditions.

Furthermore, van de Nieuwegiessen et al. (2010) showed that chronic stressors (stocking density) affect the performance traits in African catfish differently according to coping strategies. Fish housed at high density showed an increase in activity and decrease in aggression levels. In addition, at high density, reactive individuals reared in mixed groups showed a comparable growth rate to intermediate and proactive individuals. It seems that the presence of intermediate and proactive individuals stimulates the feeding motivation of reactive individuals. Undoubtedly, coping styles play an important role in how different individuals appraise the housing environment and thereby their welfare status. Huntingford \& Adams (2005) reviewed the welfare consequences of coping strategies in Salmonids. They suggest that when fish are housed at high densities and with a predictable feed source, as is usually the case in intensive husbandry systems, reactive individuals may fail to flourish. Another interesting question related with high densities, is the difference on how proactive and reactive individuals react to the suppression of aggressive behaviour induced by crowding i.e. the propensity for higher aggression in proactive individuals suggests that they will suffer most in high densities. In contrast to Huntingford \& Adams (2005), no indications were found for welfare consequences of different coping strategies in intensive husbandry systems in African catfish (van de Nieuwegiessen et al. 2010). Although an impaired growth performance of reactive fish 
480 housed in reactive groups was shown, no effects were detected in reactive fish housed in mixed

481 groups, which is the common rearing practice.

482 Based on these results, individual coping styles should not be used as a welfare indicator, but 483 one may infer a welfare problem when the behaviour identified under the proactive/reactive continuum changes. Even though, the housing environments may have profound effects on behaviour and welfare. For example, in pigs the environmental enrichment effects were shown to be much higher in LR than in HR and were reflected in more time on play behaviour and more oral manipulation of pen mates (Bolhuis et al. 2005b). In addition, the same authors showed that the effect of environmental enrichment on weight gain may differ for pigs with divergent coping styles. In fish, the effect of environmental enrichment (i.e. substrate availability) as behavioural and physiological indicators of welfare was study by Galhardo et al. (2008) whom showed that the absence of substrate decreased territorial behaviour, increase aggression levels, cortisol and glucose; all of which are suggestive of a stress-related context. This suggests that the welfare of at least some fish species may be negatively affected by the absence of substrate or other environmental enrichment, and this effect may change in distinct fish coping styles.

Furthermore, aggressiveness level is one of the differences between proactive and reactive individuals. Literature suggests that proactive individuals show high levels of aggressiveness (Øverli et al., 2004 Castanheira et al., 2013b). Aggression has been linked with a diversity of aquaculture-relevant problems including decreased feed intake, growth dispersion, chronic stress and disease vulnerability (Huntingford \& Adams 2005; Martins et al. 2011e) which as a consequence can impair fish welfare.

Moreover, Vindas et al. $(2012,2014)$ showed good evidence that Atlantic salmon possess a nervous system and a brain sufficiently complex to demonstrate individual responses to frustrations conditions when an omission of an expected reward occurs. Deviation from routine feeding practices, in intensive farming conditions, could have negative consequences, in terms of both production and welfare as a consequence of frustration-induced agonistic behaviours. 
507 Knowing that farmed fish have coping styles and that coping styles differ in how they appraise

508 their environment may help designing farming environments that are more diverse and could

509 improve the welfare of individuals with different coping styles. In turn, this may increase

510 production output.

$511 \quad$ Flesh quality

512 Nowadays there is evidence showing that inadequate fish husbandry results in lower meat

513 quality (Ribas et al. 2007; Robb et al. 2000; Matos et al., 2010, 2011). Studies show that fish

514 subjected to stress prior to and during slaughter, in particular salmonids, display a softer texture

515 and lower flesh quality (Bahuaud et al. 2010; Kiessling et al. 2004). Some studies suggest that

516 the production of low cortisol-responsive fish could benefit commercial parameters such as

517 flesh quality (Pottinger 2001). High fillet quality (e.g. textural characteristics, freshness and

518 health value) is a requirement for feed production and coping styles can attenuate or aggravate

519 the effect of stressors on filet quality. However, knowledge on the mechanisms responsible for

520 individual differences in flesh quality is still largely unknown.

521

522

Production systems

523 It is also important to understand how divergent coping styles perform in different aquaculture

524 production systems. Recirculating Aquaculture Systems (RAS), for example are expected to

525 expand in the future as they offer the possibility to have a high production with a minimum

526 ecological impact (Martins et al. 2010).

527 Mota et al. (2014) showed that steroids (glucocorticoids, androgens and a progestin) in their

528 free and conjugated forms tend to accumulate in the rearing water of commercial RAS at levels

529 that can potentially be detected by some fish species. However, we still do not know how

530 sensitive the different coping styles are to the re-uptake of steroids and olfactory cues present in

531 the water and how such sensitivity can induce different welfare levels.

532 Furthermore, the range of the coping styled spectrum that leads to maximum growth

533 performance, highest welfare condition and disease resistance, may change depending on the 
534 husbandry system, once different types of intensive, semi-intensive or extensive systems present

535 very different social and environmental conditions to fish.

\section{$536 \quad$ Future perspectives}

537 Coping styles are present in a variety of farmed fish and may impact aquaculture in different ways. However, one of the main difficulties in understanding the implications of coping styles under farming conditions is the methodology available that relies heavily on individually-based tests. Screening in isolation may induce significant stress in social species. Consequently, the development of grouped-based tests (Figure 2) may in the future facilitate mass screening of fish stocked at high densities and therefore may be more easily applied under farming conditions. Examples of potential mass screening tests are the hypoxia and the risk-taking tests

544 (Millot et al 2009b; Huntingford et al. 2010; Laursen et al. 2011; Castanheira et al. 2013b).

545 Additionally, further studies should be considered to validate the temporal consistency over

546 time of the distinct traits. One of the limitations of the available knowledge regarding the 547 temporal consistency is that it refers always to short term consistency (usually a few weeks) 548 (Basic et al. 2012; Castanheira et al. 2013b). However, van Reenen (2012) demonstrated longterm consistency of individual differences in behavioural and adrenocortical responses of dairy cattle to acute stressors. The observations were recorded in rearing period (6 - 7 months), gestation (22 - 24 months) and first lactation (25 - 29 months). They showed that individual

552 differences in struggling in a restraint test at 7 months of age predicted those in open field 553 locomotion during first pregnancy. In addition, individuals with high cortisol responses and 554 reactive behaviour measured as high avoidance and less exploration to open field and novel 555 object tests at 6 months of age, also exhibited high cortisol responses to both tests at 29 months of age. Similar studies, over longer periods of time should be undertaken also in fish. Measures of HPA axis reactivity, locomotion, vocalisation and adrenocortical and behavioural 558 responses to novelty contributed to the understanding of ability to cope with stress and 559 supporting the idea that stress responsiveness may be mediated by multiple independent underlying traits. Some authors have suggested that cortisol and behavioural responses to 
561

562

563

564

565

566

567

568

569

570

571

572

573

574

575

576

577

578

579

580

581

582

583

584

585

586

587

588

stressors are linked to two independent dimensions of stable trait characteristics (Koolhaas et al. 2010). These authors suggested that the quality of the response to a challenging condition (coping style) is independent from the quantity of that response (stress reactivity). According to the same authors, the physiological responses to stress such as the HPI axis reactivity (one of the most significant differences between proactive and reactive individuals) is more related to an emotional response to stress than to coping styles. Eventually a decoupling of these axis, coping styles and emotional, could bring new light to understand the pronounced individual variation in plasma cortisol response observed. It is also important to perform studies regarding the influence of age, environmental conditions, nutrition and social group in coping styles. In other comparative models (e.g. cows, pigs) coping styles can change partly according to the social environment (van Reenen 2012; van Erp-van der Kooij et al. 2003). In addition, van Erpvan der Kooij et al. (2003) showed that coping styles in piglets can change according to the social environment although at an older age, this ability was lost.

In addition, different coping styles also differ in their adaptability towards shifts in environmental conditions. In mice Benus et al. (1988) showed that individual differences in aggressiveness (a component trait of coping styles) explain differences in adaptation to external factors. The adaptation to a new photoperiod cycle took two fold long in the aggressive mice. However, in farmed fish there are no similar studies in literature.

Still, studies in farmed fish such as the selected trout lines can open the possibility to use fish as simpler models to understand underlying mechanism of coping styles in vertebrates such as those related to neural activity and their implications in behaviour.

The knowledge of coping styles can help to improve the sustainability of production through the establishment of more fine-tuned culture strategies. In this way the feed waste can be minimized since each coping style is related to particular physiological and behavioural responses and some culture variables could be adjusted. Moreover, the genetic basis (heritability/epigenetics) of coping styles, disease susceptibility as well the neuroendocrine mechanisms behind consistent as well as flexible behavioural patterns are here pinpointed as central themes and open research lines on application of coping styles to aquaculture. 
589

590

591

592

593

594

595

596

597

598

599

600

601

602

603

604

605

606

607

608

609

610

611

612

613

614

615

616

617

618

619

620

\section{Conclusions}

The presence of coping styles is now well recognised in farmed fish and its implication for aquaculture can be wide as here reviewed. Taken together, the fairly extensive literature on coping styles in fish shows that screening for coping styles is species-specific. The recent development of group-based tests and the use of proxies may provide an opportunity for mass screening in the future. Mass screening into different coping styles may help optimizing the production systems as optimal conditions for proactive individuals are likely to be different from those of reactive individuals.

In addition, the recognition that farmed fish exhibit coping styles means that a number of behavioural and physiological responses will vary as part of a common — pakage" that should be taken into consideration when designing selection programs.

\section{Acknowledgements}

This publication has been supported by the European Commission under the $7^{\text {th }}$ Framework Programme FP7-KBBE-2010-4 Contract no.: 265957 COPEWELL.

Competing Interests: The authors have declared that no competing interests exist.

\section{References}

Abrahams MV \& Sutterlin A (1999) The foraging and antipredator behavior of growth enhanced transgenic Atlantic salmon. Animal Behavior, 58:933-942.

Arends RJ, Mancera JM, Munoz JL, Wendelaar Bonga SE, Flik G (1999) The stress response of the gilthead sea bream (Sparus aurata L.) to air exposure and confinement. Journal of Endocrinology, 163,149-157.

Andersson MÅ, Khan UW, Overli O, Gjoen HM, Höglund E (2013a) Coupling between stress coping style and time of emergence from spawning nests in salmonid fishes: Evidence from selected rainbow trout strains (Oncorhynchus mykiss). Physiology \& Behaviour, 117, 30-34.

Andersson MÅ, Laursen DC, Silva PIM, Höglund E (2013b) The relationship between emergence from spawning gravel and growth in farmed rainbow trout Oncorhynchus mykiss. Journal of Fish Biology 83(1): 214-219. 
Andersson MÅ, Höglund E (2012) Linking personality to larval energy reserves in rainbow trout (Oncorhynchus mykiss). PLoS ONE, 7(11): e49247.

Andersson MÅ, Silva PIM, Steffensen JF, Höglund E (2011) Effects of maternal stress coping style on offspring characteristics in rainbow trout (Oncorhynchus mykiss). Hormones and Behavior 60, 699-705.

Ashley PJ (2007) Fish welfare: Current issues in aquaculture. Applied Animal Behaviour Science, 104, 199-235.

Bahuaud D, Gaarder M, Veiseth-Kent E, Thomassen M (2010) Fillet texture and protease activities in different families of farmed Atlantic salmon (Salmo salar L.). Aquaculture 310, 213-220.

Barreto REV, Volpato GL (2011) Ventilation rates indicate stress-coping styles in Nile tilapia. Journal of Bioscience, 36, 851-855.

Basic D, Winberg S, Schjolden J, Krogdahl Å, Höglund E (2012) Context-dependent responses to novelty in Rainbow trout (Oncorhynchus mykiss), selected for high and low poststress cortisol responsiveness. Physiology \& Behavior, 105, 1175-1181.

Benus RF, Bohus B, Koolhaas JM, van Oortmerssen GA (1991) Behavioural differences between artificially selected aggressive and non-aggressive mice: response to apomorphine. Behavioural Brain Research, 43, 203-208.

Benus RF, Koolhaas JM, Van Oortmerssen GA (1988) Aggression and adaptation to the lightdark cycle: Role of intrinsic and extrinsic control. Physiology \& Behavior, 43, 131-137.

Boersma G (2011) Personality and the pathophysiology of energy metabolism In: Department of neuroendocrinology. University of Groningen the Netherlands, pp. 1-242.

Bolhuis EJ, Schouten WGP, Schrama JW, Wiegant VM (2005a) Individual coping characteristics, aggressiveness and fighting strategies in pigs. Animal Behaviour, 69, 1085-1091.

Bolhuis JE, Schouten WGP, Schrama JW, WiegantVM, (2005b) Behavioural development of pigs with different coping characteristics in barren and substrate enriched housing conditions. Applied Animal Behaviour Science 93 (3-4), 213-228.

Brelin D, Petersson E, Winberg S (2005) Divergent Stress Coping Styles in Juvenile Brown Trout (Salmo trutta). Annals of the New York Academy of Sciences, 1040, 239-245.

Careau V, Thomas D, Humphries MM, Réale D (2008) Energy metabolism and animal personality. Oikos, 117, 641-653.

Castanheira MF, Herrera M, Costas B, Conceição LEC, Martins CIM (2013a) Linking cortisol responsiveness and aggressive behaviour in gilthead seabream Sparus aurata: Indication of divergent coping styles. Applied Animal Behaviour Science, 143, 75-81.

Castanheira MF, Herrera M, Costas B, Conceição LEC, Martins CIM (2013b) Can we predict personality in fish? - searching for consistency over time and across contexts. PLoS ONE 8, e62037

Chapman BB, Morrell L J, Krause J (2010) Unpredictability in food supply during early life influences boldness in fish. Behavioral Ecology, 21, 501-506

Coppens CM, De Boer SF, Koolhaas JM (2010) Coping styles and behavioural flexibility: Towards underlying mechanisms. Philosophical Transactions of the Royal Society B: Biological Sciences, 365, 4021-4028.

Dingemanse NJ, Van der Plas F, Wright J, Réale D, Schrama M, Roff DA, Van der Zee E, Barber I (2009) Individual experience and evolutionary history of predation affect expression of heritable variation in fish personality and morphology. Proceedings of the Royal Society B: Biological Sciences, 276, 1285-1293.

Ebbesson LO, Braithwaite VA (2012) Environmental effects on fish neural plasticity and cognition. Journal of Fish Biology 81 (7), 2151-2174.

Fevolden SE, Nordmo R, Refstie T, Røed KH (1993) Disease resistance in Atlantic salmon (Salmo salar) selected for high or low responses to stress. Aquaculture, 109, 215-224.

Fevolden SE, Refstie T, Røed KH (1992) Disease resistance in rainbow trout (Oncorhynchus mykiss) selected for stress response. Aquaculture, 104, 19-29.

Finstad AG, Forseth T, Ugendal O, Naese TF (2007) Metabolic rate, behaviour and winter performance in juvenile Atlantic salmon. Functional Ecology, 21, 905-912. 
Francis RC (1990) Temperament in a Fish: A Longitudinal Study of the Development of Individual Differences in Aggression and Social Rank in the Midas Cichlid. Ethology, 86, 311-325

Frost AJ, Winrow-Giffen A, Ashley PJ, Sneddon LU (2007) Plasticity in animal personality traits: does prior experience alter the degree of boldness? Proc Biol Sci., 274, 333-339.

Galhardo L, Correia J, Oliveira RF (2008) The effect of substrate availability on behavioural and physiological indicators of welfare in the African cichlid (Oreochromis mossambicus). Animal Welfare, 17, 239-254.

Gjedrem T (2005) Selection and Breeding Programs in Aquaculture, 364 p.

Gosling, Samuel D. (2001) From mice to men: What can we learn about personality from animal research? Psychological Bulletin, 127, 45-86

Herrera M, Castanheira MF, Martins CIM, Conceição LEC (2014). Link between risk taking and the behavioral and physiological responses to confinement stress in seabream Sparus aurata. Applied Animal Behaviour Science 155,101-108.

Hessing MJC, Hagelsø AM, Schouten WGP, Wiepkema PR, Van Beek JAM (1994) Individual behavioral and physiological strategies in pigs. Physiology \& Behavior, 55, 39-46.

Hessing MJC, Hagelsø AM, van Beek JAM, Wiepkema RP, Schouten WGP, Krukow R (1993) Individual behavioural characteristics in pigs. Applied Animal Behaviour Science, 37, 285-295.

Höglund E, Gjøen HM, Pottinger TG, Øverli Ø (2008) Parental stress-coping styles affect the behaviour of rainbow trout Oncorhynchus mykiss at early developmental stages. Journal of Fish Biology, 73, 1764-1769.

Hopster H (1998) Coping strategies in dairy cows. In: Institute of Animal Sciences.Wageningen University, The Netherlands, pp. 1-152.

Huntingford FA, Andrew G, Mackenzie S, Morera D, Coyle SM, Pilarczyk M, Kadri S (2010) Coping strategies in a strongly schooling fish, the common carp Cyprinus carpio. Journal of Fish Biology, 76, 1576-1591.

Huntingford FA, Adams C, Braithwaite VA, Kadri S, Pottinger TG, Sandøe P, Turnbull JF (2006) Current issues in fish welfare. Journal of Fish Biology, 68, 332-372.

Huntingford FA, Adams C (2005) Behavioural syndromes in farmed fish: implications for production and welfare. Behaviour, 142, 1213-1227.

Huntingford FA (2004) Implications of domestication and rearing conditions for the behaviour of cultivated fishes. Journal of Fish Biology, 65, 122-142.

Johansen IB, Sørensen C, Sandvik GK, Nilsson GE, Höglund E, Bakken M, Øverli Ø (2012) Neural plasticity is affected by stress and heritable variation in stress coping style. Comparative Biochemistry and Physiology Part D: Genomics and Proteomics, 7, 161171.

Johansen IB, Lunde IG, Røsjø H, Christensen G, Nilsson GE, Bakken M, Øverli Ø (2011) Cortisol response to stress is associated with myocardial remodeling in salmonid fishes. The Journal of Experimental Biology, 214, 1313-1321.

Johnson SC, Treasurer JW, Bravo S, Nagasawa K, Kabata Z (2004) A review of the impact of parasitic copepods on marine aquaculture. Zoological Studies 43 (2): 229-243.

Kiessling A, Espe M, Ruohonen K, Mørkøre T (2004) Texture, gaping and colour of fresh and frozen Atlantic salmon flesh as affected by pre-slaugher iso-eugenol or $\mathrm{CO}_{2}$ anaesthesia. Aquaculture 236, 645-657

Killen SS, Marras S, McKenzie DJ. (2011) Fuel, fasting, fear: routine metabolic rate and feed deprivation exert synergistic effects on risk-taking in individual juvenile European sea bass. Journal of Animal Ecology, 80(5),1024-33.

Kittilsen S, Johansen IB, Braastad BO, Øverli Ø (2012) Pigments, parasites and personalitiy: Towards a unifying role for steroid hormones? PLoS ONE, 7 (4), e34281.

Kittilsen S, Ellis T, Schjolden J, Braastad BO, Øverli Ø (2009a) Determining stressresponsiveness in family groups of Atlantic salmon (Salmo salar) using non-invasive measures. Aquaculture, 298, 146-152. 
Kittilsen S, Schjolden J, Beitnes-Johansen I, Shaw JC, Pottinger TG, Sørensen C, Braastad BO, Bakken M, Øverli Ø (2009b) Melanin-based skin spots reflect stress responsiveness in salmonid fish. Hormones and Behavior, 56, 292-298.

Kling GW, Hayhoe K, Johnson LB, Magnuson JJ, Polasky S, Robinson SK, Shuter BJ, Wander MW, Wuebbles DJ, Zak DR, Lindroth RL, Moser SC, Wilson ML (2003) Confronting Climate Change in the Great Lakes Region. Impacts on our Communities and Ecosystems. Union of concerned scientists, Cambridge, Massachusetts, and Ecological Society of America, Washington, D.C. (http://www.ucsusa.org/greatlakes).

Koolhaas JM, de Boer SF, Coppens CM, Buwalda B (2010) Neuroendocrinology of coping styles: Towards understanding the biology of individual variation. Frontiers in Neuroendocrinology, 31, 307-321.

Koolhaas JM, Korte SM, De Boer SF, Van Der Vegt BJ, Van Reenen CG, Hopster H, De Jong IC, Ruis MAW, Blokhuis HJ (1999) Coping styles in animals: current in behavior and stress-physiology. Neuroscience and Biobehavioral Reviews, 23, 925-935.

Korte SM, Koolhaas JM, Wingfield JC, McEwen BS (2005) The Darwinian concept of stress: Benefits of allostasis and costs of allostatic load and the trade-offs in health and disease. Neuroscience and Biobehavioral Reviews 29, 3-38.

Korte SM, Ruesink W, Blokhuis HJ (1999) Heart rate variability during manual restraint in chicks from high- and low-feather pecking lines of laying hens. Physiology \& Behavior 65 (4-5), 649-652.

Kristiansen TS, Fernö A (2007) Individual behaviour and growth af halibut (Hippoglossus hippoglossus L.) fed sinking and floating: Evidence of different coping styles. Applied Animal Behaviour Science, 104, 236-250.

Laursen DC, L. Olsén H, Ruiz-Gomez MdL, Winberg S, Höglund E (2011) Behavioural responses to hypoxia provide a non-invasive method for distinguishing between stress coping styles in fish. Applied Animal Behaviour Science 132, 211-216.

LeBlanc S, Höglund E, Gilmour KM, Currie S (2012) Hormonal modulation of the heat shock response: insights from fish with divergent cortisol stress responses. American Journal of Physiology - Regulatory, Integrative and Comparative Physiology, 302, R184-R192.

MacKenzie S, Ribas L, Pilarczyk M, Capdevila DM, Kadri S, Huntingford FA (2009) Screening for Coping Style Increases the Power of Gene Expression Studies. PLoS ONE, 4, e5314.

Magnani D, Cafazzo S, Calà P, Costa LN (2012) Searching for differences in the behavioural response of piglet groups subjected to novel situations. Behavioural Processes, 89, 6873.

Magnhagen C, Bunnefeld N (2009) Express your personality or go along with the group: what determines the behaviour of shoaling perch? Proceedings of the Royal Society B: Biological Sciences, 276, 3369-3375.

Magnhagen C (2007) Social influence on the correlation between behaviours in young-of-theyear perch. Behavioral Ecology and Sociobiology, 61, 525-531.

Magnhagen C, Staffan F (2005) Is boldness affected by group composition in young-of-the-year perch (Perca fluviatilis)? Behavioral Ecology and Sociobiology, 57, 295-303.

Martins CIM, Schaedelin FC, Mann M, Blum C, Mandl I, Urban D, Grill J, Sch, wender J, Wagner RH (2012) Exploring novelty: a component trait of behavioural syndromes in a colonial fish. Behaviour, 149, 215-231.

Martins CIM, Conceição LEC, Schrama JW (2011a) Feeding behavior and stress response explain individual differences in feed efficiency in juveniles of Nile tilapia Oreochromis niloticus. Aquaculture, 312, 192-197

Martins CIM, Silva PIM, Conceição LEC, Costas B, Höglund E, Øverli Ø, Schrama JW (2011b) Linking Fearfulness and Coping Styles in Fish. PLoS ONE, 6, e28084.

Martins CIM, Castanheira MF, Engrola S, Costas B, Conceição LEC (2011c) Individual differences in metabolism predict coping styles in fish. Applied Animal Behaviour Science, 130, 135-143.

Martins CIM, Conceição LEC, Schrama JW (2011d) Consistency of individual variation in feeding behaviour and its relationship with performance traits in Nile tilapia Oreochromis niloticus. Applied Animal Behaviour Science, 133, 109-116. 
Martins CIM, Galhardo L, Noble C, Damsgård B, Spedicato M, Zupa W, Beauchaud M, Kulczykowska E, Massabuau J-C, Carter T, Planellas S, Kristiansen T (2011e) Behavioural indicators of welfare in farmed fish. Fish Physiology and Biochemistry, 125.

Martins CIM, Eding EH, Verdegem MCJ, Heinsbroek LTN, Schneider O, Blancheton JP, d'Orbcastel ER, Verreth JAJ (2010) New developments in recirculating aquaculture systems in Europe: A perspective on environmental sustainability. Aquacultural Engineering, 43, 83-93.

Martins CIM, Hillen B, Schrama JW, Verreth JAJ (2008) A brief note on the relationship between residual feed intake and aggression behaviour in juveniles of African catfish Clarias gariepinus. Applied Animal Behaviour Science, 111, 408-413.

Martins CIM, Trenovski M, Schrama JW, Verreth JAJ (2006a) Comparison of feed intake behaviour and stress response in isolated and non-isolated African catfish. Journal of Fish Biology, 69, 629-636.

Martins CIM, Schrama JW, Verreth JAJ (2006b) The relationship between individual differences in feed efficiency and stress response in African catfish Clarias gariepinus. Aquaculture, 256, 588-595.

Martins CIM, Schrama JW, Verreth JAJ (2006c) The effect of group composition on the welfare of African catfish (Clarias gariepinus). Applied Animal Behaviour Science, 97, 323-334.

Martins CIM, Aanyu M, Schrama JW, Verreth JAJ (2005a) Size distribution in African catfish (Clarias gariepinus) affects feeding behaviour but not growth. Aquaculture, 250, 300307. Behavioural indicators of welfare in farmed fish. Fish Physiology and Biochemistry, 1-25.

Martins CIM, Schrama JW, Verreth JAJ (2005b) The consistency of individual differences in growth, feed efficiency and feeding behaviour in African catfish Clarias gariepinus (Burchell 1822) housed individually. Aquaculture Research, 36, 1509-1516.

Martins CIM, Schrama JW, Verreth JAJ (2005c) Inherent variation in growth efficiency of Africain catfish Clarias gariepinus (Burchell, 1822) juveniles. Aquaculture Research, 36, 868-875.

Matos E, Silva TS, Tiago T, Aureliano M, Dinis MT, Dias J (2011) Effect of harvesting stress and storage conditions on protein degradation in fillets of farmed gilthead seabream (Sparus aurata): A differential scanning calorimetry study. Feed Chemistry 126, 270276.

Matos E, Gonçalves A, Nunes ML, Dinis MT, Dias J (2010) Effect of harvesting stress and slaughter conditions on selected flesh quality criteria of gilthead seabream (Sparus aurata). Aquaculture 305, 66-72.

Mas-Muñoz J, Komen H, Schneider O, Visch SW, Schrama JW (2011) Feeding Behaviour, Swimming Activity and Boldness Explain Variation in Feed Intake and Growth of Sole (Solea solea) Reared in Captivity. PLoS ONE, 6, e21393.

Millot S, Cerqueira M, Castanheira MF, Øverli Ø, Martins CIM, Oliveira RF (2014a).Use of conditioned place preference/avoidance tests to assess affective states in fish. Applied Animal Behaviour Science 154,104-111.

Millot S, Péan S, Labbé L, Kerneis T, Quillet E, Dupont-Nivet M, Bégout ML (2014b). Assessment of Genetic Variability of Fish Personality Traits using Rainbow Trout Isogenic Lines. Behavior Genetics ,1-11.

Millot S, Bégout ML, Chatain B (2009a) Exploration behaviour and flight response toward a stimulus in three sea bass strains (Dicentrarchus labrax L.). Applied Animal Behaviour Science, 119, 108-114.

Millot S, Bégout ML, Chatain B (2009b) Risk-taking behaviour variation over time in sea bass Dicentrarchus labrax: effects od day-night alterations, fish phenotipic characteristics and selection for growth. Journal of Fish Biology, 75, 1733-1749.

Moreira PSA, Pulman KGT, Pottinger TG (2004) Extinction of a conditioned response in rainbow trout selected for high or low responsiveness to stress. Hormones and Behavior, 46, 450-457. 
Mota VC, Martins CIM, Eding E, Canário AV, Verreth JA (2014) Steroids accumulate in the rearing water of commercial recirculating aquaculture systems. Aquacultural Engineering (accepted).

Øverli Ø, Nordgreen J, Mejdell CM, Janczak AM, Kittilsen S, Johansen IB, Horsberg TE (2014) Ectoparasitic sea lice (Lepeophtheirus salmonis) affect behaviour and brain serotonergic activity in Atlantic salmon (Salmo salar L.): Perspectives on animal welfare. Physiology \& Behavior,

Øverli Ø, Sørensen C, Pulman KGT, Pottinger TG, Korzan W, Summers CH, Nilsson GE (2007) Evolutionary background for stress-coping styles: Relationships between physiological, behavioral, and cognitive traits in non-mammalian vertebrates. Neuroscience and Biobehavioral Reviews, 31, 396-412.

Øverli Ø, Sørensen C, Nilsson GE (2006a) Behavioral indicators of stress-coping style in rainbow trout: Do males and females react differently to novelty? Physiology \& Behavior, 87, 506-512.

Øverli Ø, Sørensen C, Kiessling A, Pottinger TG, Gjøen HM (2006b) Selection for improved stress tolerance in rainbow trout (Oncorhynchus mykiss) leads to reduced feed waste. Aquaculture 261(2): 776-781.

Øverli Ø, Winberg S, Pottinger TG (2005) Behavioral and neuroendocrine correlates of selection for stress responsiveness in rainbow trout - A review. Integrative and Comparative Biology, 45, 463-474.

Øverli Ø, Korzan WJ, Höglund E, Winberg S, Bollig H, Watt M, Forster GL, Barton BA, Øverli E, Renner KJ, Summersa CH (2004) Stress coping style predicts aggression and social dominance in rainbow trout. Hormones and Behavior 45, 235- 241.

Øverli Ø, Pottinger TG, Carrick TR, Øverli E, Winberg S (2002a) Differences in behaviour between rainbow trout selected for high- and low-stress responsiveness. Journal of Experimental Biology, 205, 391-395.

Øverli Ø, Kotzian S, Winberg S (2002b) Effects of Cortisol on Aggression and Locomotor Activity in Rainbow Trout. Hormones and Behavior, 42, 53-61.

Pottinger TG (2006) Context dependent differences in growth of two rainbow trout (Oncorhynchus mykiss) lines selected for divergent stress responsiveness. Aquaculture 256, 140-147.

Pottinger TG (2001) Effects of husbandry stress on flesh quality indicators in fish. In: Kestin SC, Warriss PD (Eds.), Farmed fish quality. Blackwell Oxford, 145-160.

Pottinger TG, Carrick TR (1999) Modification of the Plasma Cortisol Response to Stress in Rainbow Trout by Selective Breeding. General and Comparative Endocrinology, 116, 122-132.

Réale D, Dingemanse NJ, Kazem AJN, Wright J (2010a) Evolutionary and ecological approaches to the study of personality. Philosophical Transactions of the Royal Society B: Biological Sciences, 365, 3937-3946.

Réale D, Garant D, Humphries MM, Bergeron P, Careau V, Montiglio PO (2010b) Personality and the emergence of the pace-of-life syndrome concept at the population level. Philosophical Transactions of the Royal Society B-Biological Sciences 365 (1560), 4051-4063.

Réale D, Reader SM, Sol D, McDougall PT, Dingemanse NJ (2007) Integrating animal temperament within ecology and evolution. Biological reviews of the Cambridge Philosophical Society 82 (2), 291-318.

Reefmann N, Bütikofer Kaszàs F, Wechsler B, Gygax L (2009) Ear and tail postures as indicators of emotional valence in sheep. Applied Animal Behaviour Science, 118, 199207.

Reimert I, Bolhuis JE, Kemp B, Rodenburg TB (2013) Indicators of positive and negative emotions and emotional contagion in pigs. Physiology \& Behavior, 109, 42-50.

Rey S, Boltana S, Vargas R, Roher N, MacKenzie. S. (2013) Combining animal personalities with transcriptomics resolves individual variation within a wild-type zebrafish population and identifies underpinning molecular differences in brain function. Molecular Ecology 22 (24), 6100-6115. 
Rexroad C, Vallejo R, Liu S, Palti Y, Weber G (2012) QTL affecting stress response to crowding in a rainbow trout broodstock population. BioMed Central Genetics, 13 (1), 97.

Ribas L, Flos R, Reig L, MacKenzie S, Barton BA, Tort L (2007) Comparison of methods for anaesthetizing Senegal sole (Solea senegalensis) before slaughter: Stress responses and final product quality. Aquaculture 269, 250-258.

Robb DHF, Kestin SC, Warriss PD (2000) Muscle activity at slaughter: I. Changes in flesh colour and gaping in rainbow trout. Aquaculture 182, 261-269.

Ruis MAW, te Brake JHA, Engel B, Buist WG, Blokhuis HJ, Koolhaas JM (2001) Adaptation to social isolation: Acute and long-term stress responses of growing gilts with different coping characteristics. Physiology \& Behavior, 73, 541-551.

Ruiz-Gomez ML, Huntingford FA, Øverli Ø, Thörnqvist P-O, Höglund E (2011) Response to environmental change in rainbow trout selected for divergent stress coping styles. Physiology \& Behavior, 102, 317-322.

Ruiz-Gomez ML, Kittilsen S, Höglund E, Huntingford FA, Sørensen C, Pottinger TG, Bakken M, Winberg S, Korzan WJ, Øverli Ø (2008) Behavioral plasticity in rainbow trout (Oncorhynchus mykiss) with divergent coping styles: When doves become hawks. Hormones and Behavior, 54, 534-538.

Schjolden J, Backström T, Pulman KGT, Pottinger TG, Winberg S (2005) Divergence in behavioural responses to stress in two strains of rainbow trout (Oncorhynchus mykiss) with contrasting stress responsiveness. Hormones and Behavior, 48, 537-544.

Sih A, Bell A, Johnson JC (2004) Behavioral syndromes: an ecological and evolutionary overview. The Quarterly Review of Biology, 19, 372-378

Silva PIM, Martins CIM, Engrola S, Marino G, Øverli Ø, Conceição LEC (2010) Individual differences in cortisol levels and behaviour of Senegalese sole (Solea senegalensis) juveniles: Evidence for coping styles. Applied Animal Behaviour Science, 124, 75-81.

Stamps, J. A. \& Groothuis, T. G. G. (2010) The development of animal personality: relevance, concepts and perspectives. Biol. Rev. 85, 301-325.

Spake JR, Gray KA, Cassady JP (2012) Relationship between backtest and coping styles in pigs. Applied Animal Behaviour Science, 140, 146-153.

Spoolder HAM, Burbidge JA, Lawrence AB, Simmins PH, Edwards SA (1996) Individual behavioural differences in pigs: intra-and inter-test consistency. Applied Animal Behaviour Science, 49, 185-198.

Trenzado CE, Morales AE, Higuera M (2006) Physiological effects of crowding in rainbow trout, Oncorhynchus mykiss, selected for low and high stress responsiveness. Aquaculture, 258, 583-593.

Trenzado CE, Carrick TR, Pottinger TG (2003) Divergence of endocrine and metabolic responses to stress in two rainbow trout lines selected for differing cortisol responsiveness to stress. General and Comparative Endocrinology, 133, 332-340.

van de Nieuwegiessen PG, Ramli NM, Knegtel BPFJM, Verreth JAJ, Schrama JW (2010) Coping strategies in farmed African catfish Clarias gariepinus. Does it affect their welfare? Journal of Fish Biology, 76, 2486-2501.

van de Nieuwegiessen PG, Schrama JW, Verreth JAJ (2008) A note on alarm cues in juvenile African catfish, Clarias gariepinus Burchell: Indications for opposing behavioural strategies. Applied Animal Behaviour Science, 113, 270-275.

van Erp-van der Kooij E, Kuijpers AH, van Eerdenburg FJCM, Dieleman SJ, Blankenstein DM, Tielen MJM (2003) Individual behavioural characteristics in pigs - influences of group composition but no differences in cortisol responses. Physiology \& Behavior, 78, 479488.

van Reenen CG (2012) Identifying temperament in dairy cows In: Department of Livestock Research. Wageningen University, The Netherlands, pp. 1-217.

van Reenen CG, O'Connell NE, Van der Werf JTN, Korte SM, Hopster H, Jones RB, Blokhuis HJ (2005) Responses of calves to acute stress: Individual consistency and relations between behavioral and physiological measures. Physiology \& Behavior, 85, 557-570. 
van Reenen CG, Van der Werf JTN, Bruckmaier RM, Hopster H, Engel B, Noordhuizen JPTM, Blokhuis HJ (2002) Individual Differences in Behavioral and Physiological Responsiveness of Primiparous Dairy Cows to Machine Milking. Journal of Dairy Science, 85, 2551-2561.

Vaz-Serrano J, Ruiz-Gomez ML, Gjøen HM, Skov PV, Huntingford FA, Øverli Ø, Höglund E (2011) Consistent boldness behaviour in early emerging fry of domesticated Atlantic salmon (Salmo salar): Decoupling of behavioural and physiological traits of the proactive stress coping style. Physiology \& Behavior, 103, 359-364.

Veenema AH, Meijer OC, De Kloet ER, Koolhaas JM (2003) Genetic Selection For Coping Style Predicts Stressor Susceptibility. Journal of Neuroendocrinology, 15, 256-267.

Verbeek P, Iwamoto T, Murakami N (2008) Variable stress-responsiveness in wild type and domesticated fighting fish. Physiology \& Behavior, 93, 83-88.

Vindas M, Sørensen C, Johansen IB, Folkedal O, Höglund E, Khan UW, Stien L, Kristiansen T, Braastad B, Øverli Ø (2014) Coping with Unpredictability: Dopaminergic and Neurotrophic Responses to Omission of Expected Reward in Atlantic Salmon (Salmo salar). PLoS ONE 9, e85543.

Vindas M, Folkedal O, Kristiansen T, Stien L, Braastad B, Mayer I, Øverli Ø (2012) Omission of expected reward agitates Atlantic salmon (Salmo salar). Animal Cognition, 15, 903911. 
Figure 1. Distinct pigmentation profiles in Atlantic salmon defined as A) 'spotted', i.e. stress resistant and proactive and B) 'non-spotted', i.e. stress sensitive and reactive. Reproduced with permission from Kittilsen et al. 2009

Figure 2. Schematic representation of the group based tests used to determine coping styles in Gilthead seabream Sparus aurata. Reproduced with permission from Castanheira et al. 2013 
Figure 1
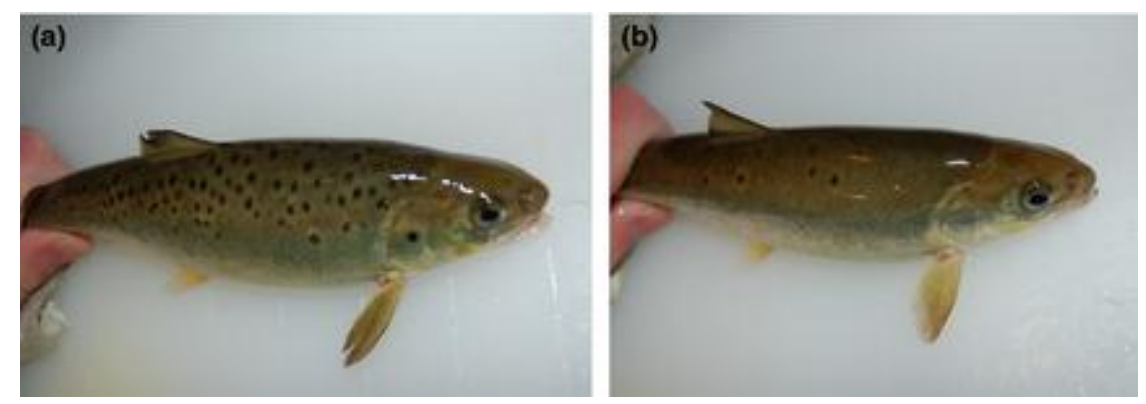

Figure 2

\section{Group-based tests}

$$
\boldsymbol{n}=\mathbf{2 4}
$$
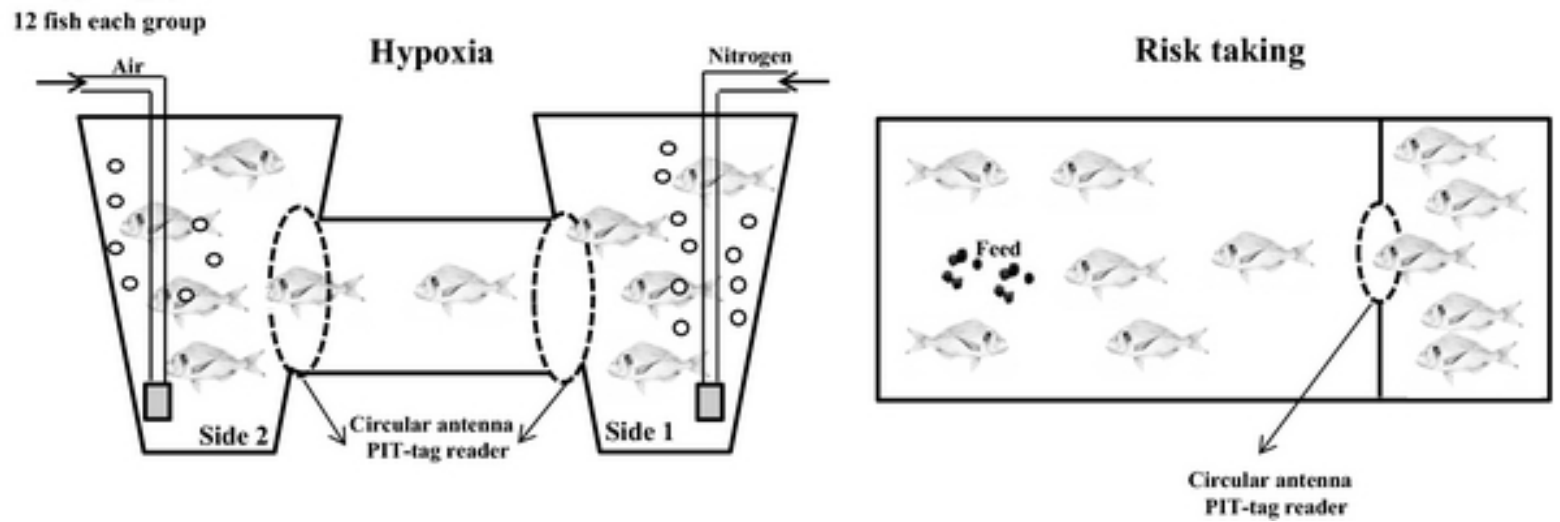
Table.1 Summary of the terminology used concerning individual variation

\begin{tabular}{|c|c|c|c|}
\hline \multicolumn{4}{|c|}{ Individual variation and Terminology } \\
\hline & Terminology & Definition & References \\
\hline $\begin{array}{c}\text { Consistency in } \\
\text { behaviour }\end{array}$ & $\begin{array}{c}\text { Personality } \\
\text { (temperament) }\end{array}$ & $\begin{array}{l}\text { Those characteristics of individuals that describe and account for consistent } \\
\text { patterns in feeling, thinking and behaving. }\end{array}$ & $\begin{array}{l}\text { Francis } 1990 \\
\text { Gosling } 2001\end{array}$ \\
\hline $\begin{array}{l}\text { Correlation between } \\
\text { behaviours }\end{array}$ & $\begin{array}{l}\text { Behavioural } \\
\text { syndromes }\end{array}$ & $\begin{array}{l}\text { A suite of correlated behaviours reflecting individual consistency } \\
\text { in behaviour across multiple situations }\end{array}$ & Shi et al. 2004 \\
\hline $\begin{array}{c}\text { Correlation between } \\
\text { behaviour and } \\
\text { physiology }\end{array}$ & $\begin{array}{l}\text { Stress coping } \\
\text { styles }\end{array}$ & $\begin{array}{l}\text { A coherent set of behavioural and physiological stress responses which is } \\
\text { consistent over time and which is characteristic of a certain group of } \\
\text { individuals }\end{array}$ & $\begin{array}{l}\text { Koolhaas et al. } \\
\quad 1999\end{array}$ \\
\hline
\end{tabular}

Table.2 Behavioural and physiological differences between proactive and reactive fish

\begin{tabular}{|c|c|c|c|}
\hline \multicolumn{4}{|l|}{ Behavioural characteristics } \\
\hline & Proactive & Reactive & References \\
\hline Actively escape to stressor & High & Low & $\begin{array}{l}\text { Silva et al. 2010; Martins et al. 2011c; } \\
\text { Brelin et al. 2005; Laursen et al. } 2011\end{array}$ \\
\hline Feed efficiency & High & Low & $\begin{array}{l}\text { Martins et al. 2005ab 2006ab; van de } \\
\text { Nieuwegiessen et al. } 2008\end{array}$ \\
\hline Feeding motivation & High & Low & $\begin{array}{c}\text { Øverli et al. } 2007 \text {; Kristiansen \& Fernö, } \\
2007\end{array}$ \\
\hline Risk taking and exploration & High & Low & $\begin{array}{l}\text { Huntingford et al. 2010; Øverli et al. 2006; } \\
\text { MacKenzie et al. 2009; Millot et al. 2009a }\end{array}$ \\
\hline Aggressiveness & High & Low & $\begin{array}{c}\text { Øverli et al. 2004, 2005; } \\
\text { Castanheira et al. } 2013\end{array}$ \\
\hline Social influence & Low & High & $\begin{array}{l}\text { Magnhagen, 2007; Magnhagen \& Staffan } \\
\text { 2005; Magnhagen \& Bunnefeld, } 2009\end{array}$ \\
\hline $\begin{array}{l}\text { Sensitive to environmental } \\
\text { stressors }\end{array}$ & Low & High & Höglund et al. 2008 \\
\hline $\begin{array}{c}\begin{array}{c}\text { Plasticity/Flexibility/Routine } \\
\text { formation }\end{array} \\
\end{array}$ & Low & High & $\begin{array}{l}\text { Chapman et al. 2010; } \\
\text { Ruiz-Gomez et al. } 2011\end{array}$ \\
\hline \multicolumn{4}{|l|}{ Physiological characteristics } \\
\hline HPI reactivity & Low & High & $\begin{array}{c}\text { Castanheira et al. 2013a; } \\
\text { Øverli et al. 2006; Trenzado et al. } 2003\end{array}$ \\
\hline Sympathetic reactivity & High & Low & $\begin{array}{c}\text { Schjolden et al. 2006; } \\
\text { Verbeek et al. 2008; } \\
\text { Barreto \& Volpato 2011 }\end{array}$ \\
\hline Parasympathetic reactivity & Low & High & $\begin{array}{l}\text { Verbeek et al. } 2008 \\
\text { Barreto \& Volpato } 2011\end{array}$ \\
\hline Hormonal modulation & Low & High & LeBlanc et al. 2012 \\
\hline Oxygen consumption & High & Low & $\begin{array}{l}\text { Herrera et al. 2014; Killen et al. 2011, } \\
\text { Martins et al. 2011c }\end{array}$ \\
\hline Myocardial dysfunction & Low & High & Johansen et al. 2011 \\
\hline Neural plasticity & Low & High & Johansen et al. 2012 \\
\hline Immunity & High & Low & Kittilsen et al. 2012 \\
\hline
\end{tabular}


Table 3 A. Summary of the evidence of coping styles in farmed fish and common tests usedFreshwater Fish

\begin{tabular}{|c|c|c|c|c|}
\hline \multicolumn{5}{|c|}{ Freshwater Fish } \\
\hline Fish Species & Tests & Screening & Observations & References \\
\hline \multirow[t]{2}{*}{$\begin{array}{l}\text { Common carp } \\
\text { (Cyprinus } \\
\text { carpio) }\end{array}$} & $\begin{array}{l}\text { Risk-taking, } \\
\text { competitive ability }\end{array}$ & Group & $\begin{array}{l}\text { Rate of exploration and competitive } \\
\text { ability are consistent over time and } \\
\text { related to risk-taking behaviour: } \\
\text { individuals that explored more quickly } \\
\text { the novel environment were the first to } \\
\text { gain access to restricted feed. }\end{array}$ & $\begin{array}{l}\text { Huntingford et al. } \\
\qquad(2010)\end{array}$ \\
\hline & Risk-taking & Group & $\begin{array}{l}\text { Individual differences in behavioural } \\
\text { responses, immune condition and } \\
\text { baseline gene expression. }\end{array}$ & $\begin{array}{l}\text { MacKenzie et al. } \\
\text { (2009) }\end{array}$ \\
\hline \multirow{3}{*}{$\begin{array}{l}\text { Nile tilapia } \\
\text { (Oreochromis } \\
\text { niloticus) }\end{array}$} & Feed intake recovery & Individual & $\begin{array}{l}\text { Individual differences in ventilation rate } \\
\text { and correlate with the rate of feeding } \\
\text { recovery in isolation. }\end{array}$ & $\begin{array}{c}\text { Barreto \& } \\
\text { Volpato, } 2011\end{array}$ \\
\hline & Feed intake recovery & Individual & $\begin{array}{l}\text { Proactive individuals seem to exhibit a } \\
\text { faster recovery of feed intake after } \\
\text { transfer into a novel environment and use } \\
\text { feed resources more efficiently. }\end{array}$ & $\begin{array}{l}\text { Martins et al. } \\
\text { (2011 bd) }\end{array}$ \\
\hline & $\begin{array}{l}\text { Feed intake recovery, } \\
\text { novel object, } \\
\text { restraining }\end{array}$ & Individual & $\begin{array}{l}\text { Inclusion of emotional reactivity } \\
\text { (fearfulness) and appraisal as } \\
\text { discriminating variables between reactive } \\
\text { and proactive individuals. }\end{array}$ & $\begin{array}{l}\text { Martins et al. } \\
\text { (2011a) }\end{array}$ \\
\hline \multirow{4}{*}{$\begin{array}{l}\text { African catfish } \\
\quad \text { (Clarias } \\
\text { gariepinus) }\end{array}$} & $\begin{array}{l}\text { Feed intake recovery, } \\
\text { feeding behaviour }\end{array}$ & $\begin{array}{l}\text { Individual + } \\
\text { Group }\end{array}$ & $\begin{array}{l}\text { Proactive individuals seem to exhibit a } \\
\text { faster recovery of feed intake after } \\
\text { transfer into a novel environment and use } \\
\text { feed resources more efficiently. Feeding } \\
\text { behaviour could be used as a predictor of } \\
\text { feed efficiency. }\end{array}$ & $\begin{array}{l}\text { Martins et al. } \\
\qquad(2005 \mathrm{ab} \\
2006 \mathrm{abc})\end{array}$ \\
\hline & $\begin{array}{l}\text { Feed intake, } \\
\text { aggression }\end{array}$ & $\begin{array}{c}\text { Individual + } \\
\text { Pairwise }\end{array}$ & $\begin{array}{l}\text { Individual differences in residual feed } \\
\text { intake are related with differences in } \\
\text { aggressive behaviour: more efficient } \\
\text { individuals are more aggressive. }\end{array}$ & $\begin{array}{l}\text { Martins et al. } \\
\quad(2008)\end{array}$ \\
\hline & $\begin{array}{c}\text { Alarm cues, feeding } \\
\text { behaviour }\end{array}$ & Individual & $\begin{array}{l}\text { Feeding efficiency (residual feed intake) } \\
\text { related with opposite behavioural } \\
\text { responses to conspecific skin extract. }\end{array}$ & $\begin{array}{l}\text { van de } \\
\text { Nieuwegiessen } \\
\text { et al. }(2008) \\
\end{array}$ \\
\hline & Escape test & $\begin{array}{l}\text { Individual + } \\
\text { Group }\end{array}$ & $\begin{array}{l}\text { Behavioural responses to the escape test } \\
\text { (after a group-housed period) changed } \\
\text { according to the group composition. }\end{array}$ & $\begin{array}{c}\text { van de } \\
\text { Nieuwegiessen } \\
\text { et al. }(2010)\end{array}$ \\
\hline $\begin{array}{c}\text { Perch } \\
(\text { Perca } \\
\text { fluviatilis })\end{array}$ & $\begin{array}{l}\text { Habitat utilisation and } \\
\text { feeding activity } \\
\text { in visual contact with a } \\
\text { potential predator, } \\
\text { Risk-taking }\end{array}$ & $\begin{array}{c}\text { Individual }+ \\
\text { Group }\end{array}$ & $\begin{array}{l}\text { Proactive individuals spent more time in } \\
\text { the open field and tended to be faster to } \\
\text { enter in unknown environments. } \\
\text { Modulation of individual behaviours by } \\
\text { other group members. }\end{array}$ & $\begin{array}{l}\text { Magnhagen \& } \\
\text { Staffan (2005) } \\
\text { Magnhagen (2007) } \\
\text { Magnhagen } \\
\text { \&Bunnefeld } \\
\text { (2009) }\end{array}$ \\
\hline
\end{tabular}


Table 3 B. Summary of the evidence of coping styles in farmed fish and common tests usedDiadromous Fish

\begin{tabular}{|c|c|c|c|c|}
\hline \multicolumn{5}{|c|}{ Diadromous Fish } \\
\hline \multirow{3}{*}{$\begin{array}{c}\text { Atlantic } \\
\text { salmon } \\
\text { (Salmo salar) }\end{array}$} & $\begin{array}{l}\text { High/Low stress } \\
\text { response }\end{array}$ & - & $\begin{array}{l}\text { Individual differences in disease } \\
\text { resistance in lines selected for high and } \\
\text { low post stress plasma cortisol levels. }\end{array}$ & $\begin{array}{l}\text { Fevolden et al. } \\
\text { (1993) }\end{array}$ \\
\hline & $\begin{array}{l}\text { Feeding in isolation, } \\
\text { confinement }\end{array}$ & Individual & $\begin{array}{l}\text { HR (more reactive) fish showed } \\
\text { increased susceptibility to infectious. } \\
\text { Pigmentation profiles are correlated with } \\
\text { stress cortisol response. Distinct } \\
\text { vulnerability to parasites correlates with } \\
\text { pigmentation (high/low black skin spots). }\end{array}$ & $\begin{array}{l}\text { Kittilsen et al. } \\
(2009 ; 2012)\end{array}$ \\
\hline & $\begin{array}{c}\text { Resume feeding in } \\
\text { isolation }\end{array}$ & Individual & $\begin{array}{l}\text { Early emerging individuals showed a } \\
\text { shorter time to resume feeding after } \\
\text { transfer to rearing in isolation. }\end{array}$ & $\begin{array}{l}\text { Vaz-Serrano et al. } \\
\text { (2011) }\end{array}$ \\
\hline \multirow{11}{*}{$\begin{array}{l}\text { Rainbow trout } \\
\text { (Oncorhynchus } \\
\text { mykiss) }\end{array}$} & Aggression & Pairwise & $\begin{array}{l}\text { Lower brain serotonergic activity in } \\
\text { socially naïve fry with big yolk and } \\
\text { higher propensity for social dominance } \\
\text { and aggression. }\end{array}$ & $\begin{array}{l}\text { Andersson \& } \\
\text { Höglund (2012) }\end{array}$ \\
\hline & $\begin{array}{l}\text { Emergence from } \\
\text { spawning gravel }\end{array}$ & Group & $\begin{array}{l}\text { Relationship between characteristics } \\
\text { expressed in early development and stress } \\
\text { coping styles. The LR fish line has bigger } \\
\text { eggs, yolk reserves and faster } \\
\text { developmental rate. }\end{array}$ & $\begin{array}{l}\text { Andersson et al. } \\
\qquad(2013 \mathrm{a}, \mathrm{b})\end{array}$ \\
\hline & $\begin{array}{l}\text { Novel object, } \\
\text { resident intruder, } \\
\text { confinement }\end{array}$ & Individual & $\begin{array}{l}\text { Individual differences were behavioural } \\
\text { constant, but no differences were } \\
\text { found between LR-HR lines. }\end{array}$ & $\begin{array}{l}\text { Basic et al. } \\
\quad(2012)\end{array}$ \\
\hline & Confinement & Group & $\begin{array}{l}\text { Inflammatory challenge with bacterial } \\
\text { pathogens reported distinct disease } \\
\text { resistance between coping styles. }\end{array}$ & $\begin{array}{l}\text { Fevolden et al. } \\
\qquad(1992)\end{array}$ \\
\hline & Novel object & Individual & $\begin{array}{l}\text { Social context is an important modulator } \\
\text { of coping styles. Bold fish may be more } \\
\text { flexible to changing conditions as } \\
\text { opposed to shy individuals. }\end{array}$ & $\begin{array}{l}\text { Frost et al. } \\
\quad(2007)\end{array}$ \\
\hline & $\begin{array}{l}\text { Initiation of avoidance } \\
\text { swimming (larvae) }\end{array}$ & Individual & $\begin{array}{l}\text { Yolk-sac fry originating from the HR } \\
\text { strain were more sensitive to } \\
\text { environmental stressors, and have shown } \\
\text { a shorter reaction time to low oxygen } \\
\text { levels. }\end{array}$ & $\begin{array}{l}\text { Höglund et al. } \\
\qquad(2008)\end{array}$ \\
\hline & Confinement & Individual & $\begin{array}{l}\text { HR fish seem to be associated with } \\
\text { cardiac remodeling and altered gene } \\
\text { expression. }\end{array}$ & $\begin{array}{l}\text { Johansen et al. } \\
\qquad(2011)\end{array}$ \\
\hline & $\begin{array}{l}\text { Confinement, social } \\
\text { stress (dominant } \\
\text { resident fish) }\end{array}$ & $\begin{array}{l}\text { Individual }+ \\
\text { Group }\end{array}$ & $\begin{array}{l}\text { Neurobiological mechanism } \\
\text { underpinning differences in plasticity } \\
\text { associated with distinct coping styles. }\end{array}$ & $\begin{array}{l}\text { Johansen et al. } \\
\qquad(2012)\end{array}$ \\
\hline & Confinement & Individual & $\begin{array}{l}\text { Differences between the HR-LR fish } \\
\text { strain in the degree of pigmentation. }\end{array}$ & $\begin{array}{l}\text { Kittilsen et al. } \\
(2009 \mathrm{~b})\end{array}$ \\
\hline & Hypoxia & Group & $\begin{array}{l}\text { Behavioural responses to hypoxia can be } \\
\text { used as a non-invasive method for sorting } \\
\text { fish according to stress coping styles. }\end{array}$ & $\begin{array}{l}\text { Laursen et al. } \\
\qquad(2011)\end{array}$ \\
\hline & $\begin{array}{l}\text { Confinement, heat } \\
\text { shock, feed intake } \\
\text { recovery }\end{array}$ & Individual & $\begin{array}{l}\text { HR fish has a general response to } \\
\text { environmental changes reflected in their } \\
\text { greater and faster heat shock response } \\
\text { and lower oxidative protein damage in } \\
\text { response to high temperatures. }\end{array}$ & $\begin{array}{l}\text { LeBlanc et al. } \\
\qquad(2012)\end{array}$ \\
\hline
\end{tabular}




\begin{tabular}{|c|c|c|c|c|}
\hline & $\begin{array}{l}\text { Exploratory behaviour, } \\
\text { Risk-taking }\end{array}$ & $\begin{array}{l}\text { Individual + } \\
\text { Group }\end{array}$ & $\begin{array}{l}\text { The importance of the genetic regulation: } \\
\text { isogenic lines with contrasted behavioural } \\
\text { responses to a set of environmental } \\
\text { stimuli. }\end{array}$ & $\begin{array}{l}\text { Millot et al. } \\
\quad(2014 \mathrm{~b})\end{array}$ \\
\hline & $\begin{array}{l}\text { Emersion, } \\
\text { confinement }\end{array}$ & Group & $\begin{array}{l}\text { HR-LR individuals differed in memory } \\
\text { retention. }\end{array}$ & $\begin{array}{l}\text { Moreira et al. } \\
\quad(2004)\end{array}$ \\
\hline & $\begin{array}{l}\text { Locomotor activity, } \\
\text { smaller conspecific } \\
\text { intruder, feed intake }\end{array}$ & $\begin{array}{l}\text { Individual + } \\
\text { Pairwise }\end{array}$ & $\begin{array}{l}\text { Behavioural and physiological } \\
\text { differences between HR and LR fish } \\
\text { established differences in performance. }\end{array}$ & $\begin{array}{l}\text { Øverli et al. } \\
\quad(2002)\end{array}$ \\
\hline & $\begin{array}{l}\text { Aggressive behaviour, } \\
\text { feed intake, } \\
\text { confinement }\end{array}$ & $\begin{array}{l}\text { Individual + } \\
\text { Pairwise }\end{array}$ & $\begin{array}{l}\text { LR fish were more aggressive when } \\
\text { placed in a dominant social position. }\end{array}$ & $\begin{array}{l}\text { Øverli et al. } \\
\quad(2004 \mathrm{a})\end{array}$ \\
\hline & $\begin{array}{l}\text { Confinement, } \\
\text { locomotor activity, feed } \\
\text { intake }\end{array}$ & Individual & $\begin{array}{l}\text { Individual differences in behavioural } \\
\text { responses. Synthesis and metabolism of } \\
\text { monoamine neurotransmitters and their } \\
\text { metabolites were elevated after stress to a } \\
\text { larger degree in HR fish. }\end{array}$ & $\begin{array}{l}\text { Øverli et al. } \\
\quad(2004 \mathrm{~b})\end{array}$ \\
\hline & $\begin{array}{l}\text { Feed intake recovery, } \\
\text { confinement }\end{array}$ & Individual & $\begin{array}{l}\text { Behavioural indicators of stress-coping } \\
\text { styles related with sex difference. } \\
\text { Immature males resumed feeding after } \\
\text { transfer to social isolation quicker than } \\
\text { males. Females settling down and ceasing } \\
\text { to move in a panic-like manner quicker } \\
\text { than males during the confinement. }\end{array}$ & $\begin{array}{l}\text { Øverli et al. } \\
\quad(2006 a)\end{array}$ \\
\hline & $\begin{array}{l}\text { Crowded/ uncrowded } \\
\text { conditions }\end{array}$ & Group & $\begin{array}{l}\text { Distinct susceptibility under crowded } \\
\text { condition and more feed waste in units } \\
\text { containing HR when transported. }\end{array}$ & $\begin{array}{l}\text { Øverli et al. } \\
\text { (2006b) }\end{array}$ \\
\hline & Feeding behaviour & Individual & $\begin{array}{l}\text { Differences in responsiveness to } \\
\text { environmental change: LR fish shown to } \\
\text { develop routines more easily. }\end{array}$ & $\begin{array}{l}\text { Ruiz-Gomez et al. } \\
\qquad \text { (2011) }\end{array}$ \\
\hline & $\begin{array}{l}\text { Feed intake recovery, } \\
\text { conspecific intruder }\end{array}$ & $\begin{array}{l}\text { Individual + } \\
\text { Pairwise }\end{array}$ & $\begin{array}{l}\text { Behavioural plasticity is limited by } \\
\text { genetic factors determining social } \\
\text { position in early life. Some behavioural } \\
\text { differences can be modified by } \\
\text { experience. }\end{array}$ & $\begin{array}{l}\text { Ruiz-Gomez et al. } \\
\qquad(2008)\end{array}$ \\
\hline & Confinement & Group & $\begin{array}{l}\text { Differences between the HR-LR fish in } \\
\text { plasma amino acids and liver glycogen } \\
\text { concentration. }\end{array}$ & $\begin{array}{l}\text { Trenzado et al. } \\
\qquad \text { (2003) }\end{array}$ \\
\hline & $\begin{array}{l}\text { Crowded/ uncrowded } \\
\text { conditions }\end{array}$ & Group & $\begin{array}{l}\text { Performance discrepancy between the } \\
\text { HR-LR fish related with competitiveness/ } \\
\text { aggressiveness. Differences in plasma } \\
\text { glucose levels and glycogen levels. }\end{array}$ & $\begin{array}{l}\text { Trenzado et al. } \\
\quad(2006)\end{array}$ \\
\hline $\begin{array}{l}\text { Brown Trout } \\
\text { (Salmo trutta) }\end{array}$ & $\begin{array}{l}\text { Feed intake recovery, } \\
\text { resident-intruder, } \\
\text { hypoxia, confinement }\end{array}$ & Individual & $\begin{array}{l}\text { Individual differences in behavioural } \\
\text { responses on resident-intruder, hypoxia } \\
\text { and confinement. No differences in feed } \\
\text { intake recovery. }\end{array}$ & $\begin{array}{l}\text { Brelin et al. } \\
\quad(2005)\end{array}$ \\
\hline
\end{tabular}


Table 3 C. Summary of the evidence of coping styles in farmed fish and common tests usedMarine Fish

\begin{tabular}{|c|c|c|c|c|}
\hline \multicolumn{5}{|c|}{ Marine Fish } \\
\hline \multirow{3}{*}{$\begin{array}{l}\text { Gilthead Sea } \\
\text { bream } \\
\text { (Sparus } \\
\text { aurata) }\end{array}$} & $\begin{array}{l}\text { Restraining, } \\
\text { aggression }\end{array}$ & $\begin{array}{l}\text { Individual + } \\
\text { Pairwise }\end{array}$ & $\begin{array}{l}\text { Fish with lower cortisol levels (proactive) } \\
\text { when exposed to stress are more } \\
\text { aggressive. }\end{array}$ & $\begin{array}{l}\text { Castanheira et al. } \\
\text { (2013b) }\end{array}$ \\
\hline & $\begin{array}{l}\text { Feed intake recovery, } \\
\text { novel object, } \\
\text { restraining, risk-taking }\end{array}$ & $\begin{array}{l}\text { Individual + } \\
\text { Group }\end{array}$ & $\begin{array}{l}\text { Behavioural differences are consistent } \\
\text { over time and predictable based on other } \\
\text { behaviours. Possibility to predict } \\
\text { behaviour in groups from individual } \\
\text { personality traits. }\end{array}$ & $\begin{array}{l}\text { Castanheira et al. } \\
\text { (2013a) }\end{array}$ \\
\hline & Risk-taking, hypoxia & $\begin{array}{l}\text { Individual + } \\
\text { Group }\end{array}$ & $\begin{array}{l}\text { Risk-avoiders (reactive) behaviours were } \\
\text { negatively correlated to movement and } \\
\text { oxygen consumption rates in metabolic } \\
\text { chambers. }\end{array}$ & $\begin{array}{l}\text { Herrera et al. } \\
\quad(2014)\end{array}$ \\
\hline \multirow{3}{*}{$\begin{array}{c}\text { Sea bass } \\
\text { (Dicentrarchus } \\
\text { labrax) }\end{array}$} & $\begin{array}{l}\text { Feed intake recovery, } \\
\text { exploration, restraining, } \\
\text { risk-taking, hypoxia }\end{array}$ & $\begin{array}{l}\text { Individual + } \\
\text { Group }\end{array}$ & $\begin{array}{l}\text { Behavioural differences were not } \\
\text { consistent over time or across context in } \\
\text { individual-based tests. In contrast, strong } \\
\text { individual consistency was observed for } \\
\text { all variables measured in group based } \\
\text { tests. Hypoxia-avoiders had lower } \\
\text { cortisol rate, higher activity and were } \\
\text { higher risk-takers: the } 3 \text { characteristics of } \\
\text { proactive coping style }\end{array}$ & $\begin{array}{l}\text { Ferrari et al. } \\
\quad(2014)\end{array}$ \\
\hline & $\begin{array}{c}\text { Exploration }+ \\
\text { swimming activities } \\
\text { after a stimulation }\end{array}$ & Individual & $\begin{array}{l}\text { Whatever the level of domestication and } \\
\text { selection for growth fish presented the } \\
\text { same flight response and stimulus } \\
\text { exposure induced a significant decrease } \\
\text { in exploratory behaviour and swimming } \\
\text { activity. Only one generation of captivity } \\
\text { could be sufficient to obtain fish } \\
\text { presenting the same coping style } \\
\text { characteristics (bolder) than fish reared } \\
\text { for at least two generations. }\end{array}$ & $\begin{array}{l}\text { Millot et al. } \\
\quad \text { (2009a) }\end{array}$ \\
\hline & Risk-taking & Group & $\begin{array}{l}\text { Wild fish were generally bolder than } \\
\text { selected fish during two first days of } \\
\text { test but showed a decrease in risk } \\
\text { taking behaviour during a third day } \\
\text { test. Selected fish showed a constant } \\
\text { increase in their risk-taking behaviour } \\
\text { over time. }\end{array}$ & $\begin{array}{l}\text { Millot et al. } \\
\quad(2009 \mathrm{~b})\end{array}$ \\
\hline \multirow{2}{*}{$\begin{array}{l}\text { Senegalese } \\
\text { sole } \\
(\text { Solea } \\
\text { senegalensis })\end{array}$} & $\begin{array}{l}\text { Feed intake recovery, } \\
\text { restraining }\end{array}$ & Individual & $\begin{array}{l}\text { Proactive fish exhibit shorter feeding } \\
\text { latency, higher duration of escape } \\
\text { attempts and lower undisturbed cortisol } \\
\text { levels than passive individuals. }\end{array}$ & $\begin{array}{l}\text { Silva et al. } \\
\quad(2010)\end{array}$ \\
\hline & Restraining & Individual & $\begin{array}{l}\text { Individual differences in metabolism are } \\
\text { predictive of distinct coping styles. }\end{array}$ & $\begin{array}{l}\text { Martins et al. } \\
\text { (2011a) }\end{array}$ \\
\hline $\begin{array}{c}\text { Sole } \\
\text { (Solea solea) }\end{array}$ & $\begin{array}{l}\text { Novel environment, } \\
\text { light avoidance, } \\
\text { feeding efficiency }\end{array}$ & $\begin{array}{l}\text { Group }+ \\
\text { Individual }\end{array}$ & $\begin{array}{l}\text { Proactive fish (high swimming activity) } \\
\text { were most feed efficient and grew faster. }\end{array}$ & $\begin{array}{l}\text { Mas-Muñoz et al. } \\
\text { (2011) }\end{array}$ \\
\hline $\begin{array}{c}\text { Halibut } \\
\text { (Hippoglossus } \\
\text { hippoglossus) }\end{array}$ & $\begin{array}{l}\text { Swimming behaviour, } \\
\text { feed intake }\end{array}$ & Group & $\begin{array}{l}\text { Reactive individuals were unable to } \\
\text { adapt, or adapted very slowly, to floating } \\
\text { feed showed decreased feed intake and } \\
\text { increased stereotypic (surface swimming) } \\
\text { activity - reflects high routine formation. }\end{array}$ & $\begin{array}{l}\text { Kristiansen \& } \\
\text { Fernö } \\
(2007)\end{array}$ \\
\hline
\end{tabular}

